\title{
Air Quality of a Parking Building in Makassar (A Case Study of Bosowa Tower Parking Building)
}

\author{
Nasrul $^{\mathrm{a}, *}$, Baharuddin Hamzah ${ }^{\mathrm{b}}$, Rosady Mulyadi ${ }^{\mathrm{c}}$ \\ aDepartment of Architecture, Faculty of Engineering, Hasanuddin University. Email: nasru19891@gmail.com \\ bDepartment of Architecture, Faculty of Engineering, Hasanuddin University. Email: baharsyah@unhas.ac.id \\ 'Department of Architecture, Faculty of Engineering, Hasanuddin University. Email: rosady@unhas.ac.id
}

\begin{abstract}
This study aims to determine the level of air quality in the parking building based on the pollution content in it $\left(\mathrm{CO}_{1} \mathrm{CO}_{2}, \mathrm{HCHO}\right.$ and, VOC), to analyze the effect of the weather, intensity of motorized vehicle traffic, and surface elevation to the air quality. The dependent variable is the level of air pollution. The research sample is the Makassar Bosowa Tower Parking Building, data collection was carried out by direct measurement and observation in 12 days from November 24, 2020 till December 17, 2020. The research was done using the comparative method, The data was processed using the Mann-Whitney difference test, and the Spearman correlation test using the SPSS application. The results showed that the average CO levels had exceeded the limit of good air quality, the average of $\mathrm{CO}_{2}$ levels was still within the limits for good air quality, and the average of HCHO and VOC levels were mostly within the limits for good indoor air quality, according to The Indonesia Minister of Health Regulation Number 1077 in 2011. The result of measurements and tests shows that the changes in the weather do not have a significant effect on the air quality. The amount and the intensity of motorized vehicle traffic affect the air quality, especially during rainy weather.
\end{abstract}

Keywords: Air quality; motorized vehicle; parking building; pollution; weather

\section{Introduction}

Indonesia is a tropical country that only has two seasons, namely the rainy season and the dry season [1], Makassar City is still being chosen by various countries to invest in [2], which make Makassar City is one of the cities with rapid development conditions in Indonesia [3].

The major contributor to increasing air pollution in Indonesia is motorized vehicles, considering that from the year 2004 - 2014, there has been a very rapid surge in the number of motorized vehicles, and approximately $70 \%$ are distributed in urban areas [4]. Meteorological parameters are also affected pollutant levels in the air, air temperature and humidity are part of meteorological parameters that can affect pollutant levels in the air [5].

Urban areas often have temperatures 1-6 degrees Celsius higher than the surrounding areas (rural areas), this phenomenon is known as an "Urban Heat Island" (UHI) [6]. Part of the building that could be a source of pollution is the parking area, since the parking area is a place for motorized vehicles to pass which is the main cause of pollution in urban areas, from the description above the objective of this study is:

- To determine the level of air quality in the parking building based on the pollution content in it.

- To analyze the effect of the weather on the air quality.

${ }^{\star}$ Corresponding author. Tel.: +62811989124

Hasyim Street No. 2 Tamalatea, Jeneponto Regency, Makassar, Indonesia, 92351
- To analyze the changes in the air quality based on the intensity of motorized vehicle traffic and surface elevation.

\section{Study Literature}

Good air quality is the air that has a low pollution content, and the levels of air pollution that are important to review in this study are Carbon Monoxide (CO), Carbon Dioxide $\left(\mathrm{CO}_{2}\right)$, Formaldehyde $(\mathrm{HCHO})$, and Volatile Organic Compound (VOC).

The main cause of the emergence of Carbon Monoxide (CO) in cars is when the element of oxygen (air), complete combustion does not occur so that the carbon in the fuel does not burn completely. This is due to the imperfect mixing of fuel and air, causing the mixture to be difficult to burn completely or the combustion time is too fast [7].

Causes of increasing of the Carbon Dioxide $\left(\mathrm{CO}_{2}\right)$ to levels that can be dangerous, is smoking in the house, numbers of the occupant in the room are very high, and using the fuels material such as charcoal, wood, petroleum, and coal [8]. Formaldehyde (HCHO) is produced by burning carbon-containing materials, in the atmosphere, $\mathrm{HCHO}$ is produced from the reaction of sunlight and oxygen to methane and other hydrocarbons in the atmosphere. Formaldehyde can be used to eradicate most bacteria, so it is often used as a disinfectant and also as a preservative [9]. 
Volatile Organic Compound (VOC) is a compound containing carbon, that evaporates at a certain pressure and temperature, or has a high vapor pressure at room temperature, the most commonly known VOCs are solvents, other types of VOCs such as monomers and fragrances, If VOC reacts with Nitrogen Oxide (NOx) and is exposed to sunlight to form ground-level ozone or fog, at certain concentrations in the air, ozone can affect health and the environment [10]. The limit of pollution levels to maintain indoor air quality is shown in Table 1.

Table 1. Chemical requirements for indoor air quality [8]

\begin{tabular}{ccccc}
\hline No & Parameter Type & Unit & $\begin{array}{c}\text { Required } \\
\text { Rate }\end{array}$ & Information \\
\hline 1 & $\mathrm{CO}$ & Ppm & 9 & 8 Hour \\
2 & $\mathrm{CO}_{2}$ & Ppm & 1000 & 8 Hour \\
3 & $\mathrm{HCHO}$ & $\mathrm{Ppm}$ & 0.1 & 30 Minute \\
4 & VOC & Ppm & 3 & 8 Hour \\
\hline
\end{tabular}

Indirectly, air temperature also plays a role in the formation of secondary pollutants because solar radiation and air temperature have an interrelated correlation, air temperature can affect the increase in chemical reactions in the atmosphere and result in the formation of fine particulates naturally [11]. Humid air will help the process of deposition of pollutants because, with the humid condition in the air, some pollutants in the form of particles will bind to the water in the air and form larger particles so that they easily settle to the earth's surface by the earth's gravity [12].

\section{Research Methods}

This research using quantitative method, and process in the quantitative research to find information uses data in form of numbers, to analyze the information about what you want to know [13], and the type of this research is comparative quantitative, where the comparative quantitative is a type of research that intended to find the differences in the studied variables [14].

The object of this study is the Makassar Bosowa Tower Parking Building, because Makassar City is one of the main growth centers in Indonesia, and also because the Bosowa Makassar Tower is the building with the largest office function in Makassar City, so the number of building users is very large according to the work hour, and consistently every week.

The Makassar Bosowa Tower parking building consists of six floors, each floor is divided into two (split floors), where each floor is an area for parking for fourwheeled vehicles/cars and is located separately from the main building of the Makassar Bosowa Tower. The placement of the measuring point is in the center of each floor in the measurement area, it is expected to be able to take the average value of air quality over the entire floor area, by determining the measuring point in the Split Floor Upper-Level area. The minimum height of the measuring instrument is at a height of 0.5 meters from the floor surface [15], and the measuring instrument is placed at that height.

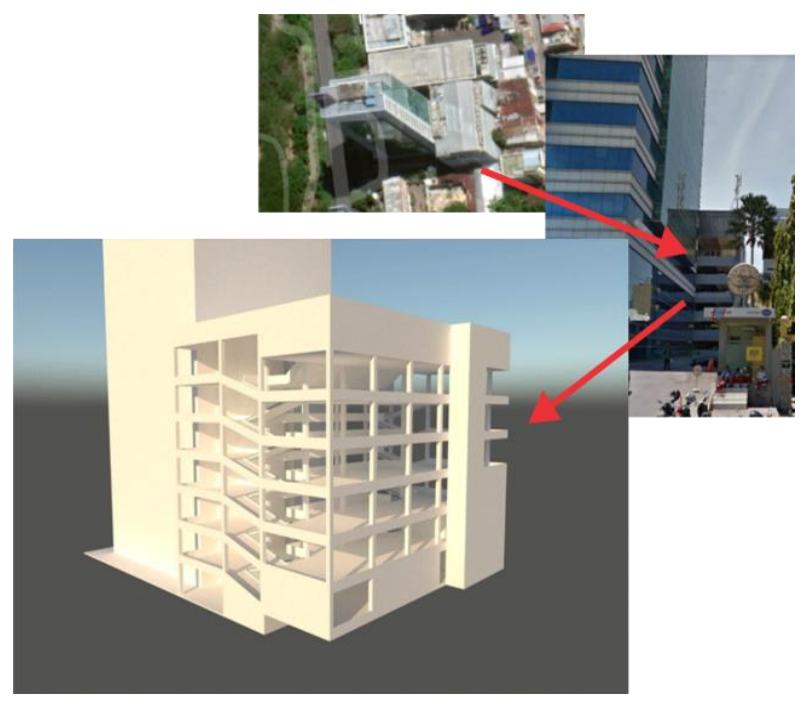

Figure 1. Makassar Bosowa Tower Parking building

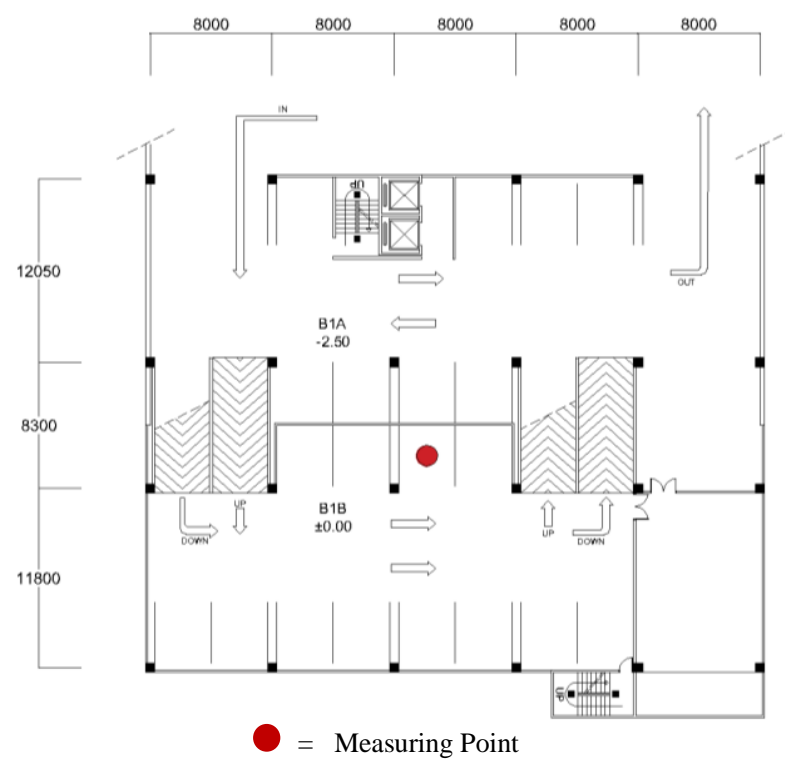

Figure 2. Makassar Bosowa Tower Parking building

Data was collected by direct measurement and observation in 12 days from November 24, 2020 till December 17, 2020 in two different types of weather which six-day when the sunny day and also six-day when the rainy day, and to measure the level of air pollution an "Air Quality Detector" is used, and to measure the air temperature and humidity a "Thermo Hygrometer HTC1 " is used.

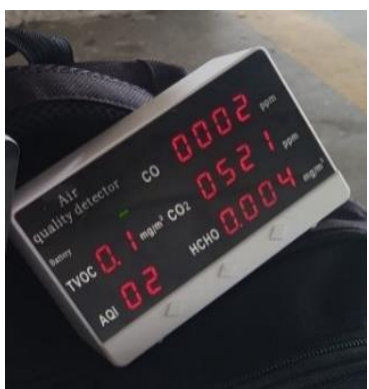

a

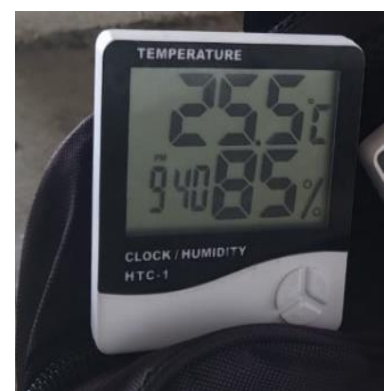

b
Figure 3. (a) Air quality detector; (b) Thermo Hygrometer HTC-1 
Table 2. Research variables and indicators

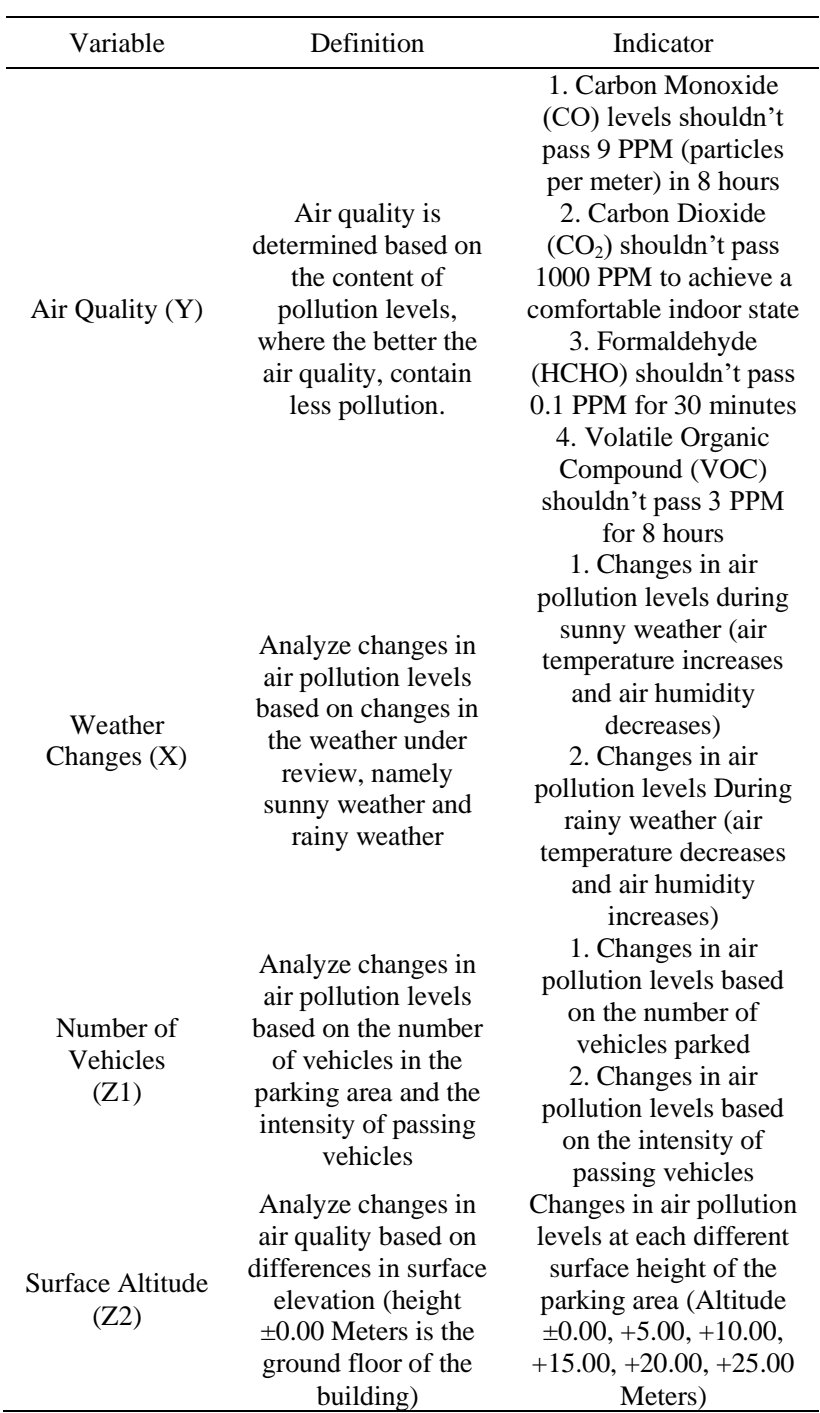

The dependent variable ( $\mathrm{Y}$ ) in this study is the concentration of $\mathrm{CO}, \mathrm{CO}_{2}, \mathrm{HCHO}$, and $\mathrm{VOC}$, to determine the air quality, the independent variable $(\mathrm{X})$ in this study is the weather changes from a sunny day, to a rainy day, Intervening variable $(Z)$ in this study is the effect of motorized vehicles and surface height, explanation about the variable indicator can be seen at Table 2.

\section{Result and Discussion}

\subsection{Measurement results}

Measurements of air pollutant levels, namely Carbon Monoxide (CO), Carbon Dioxide $\left(\mathrm{CO}_{2}\right)$, Formaldehyde (HCHO), and Volatile Organic Compound (VOC), were carried out on each floor at an altitude of $\pm 0.00,+5.00$, $+10.00,+15.00,+20.00$ and +25.00 Meters based on the building level, and carried out when the weather is sunny and rainy with each measurement result can be seen in Fig. 4.

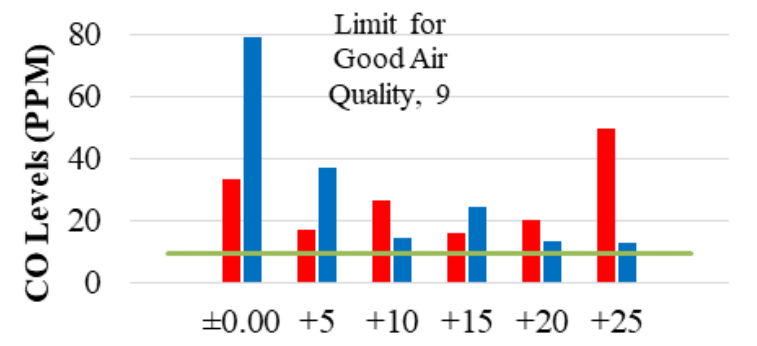

Surface Height (Meter)

- Sunny $\bullet$ Rainy
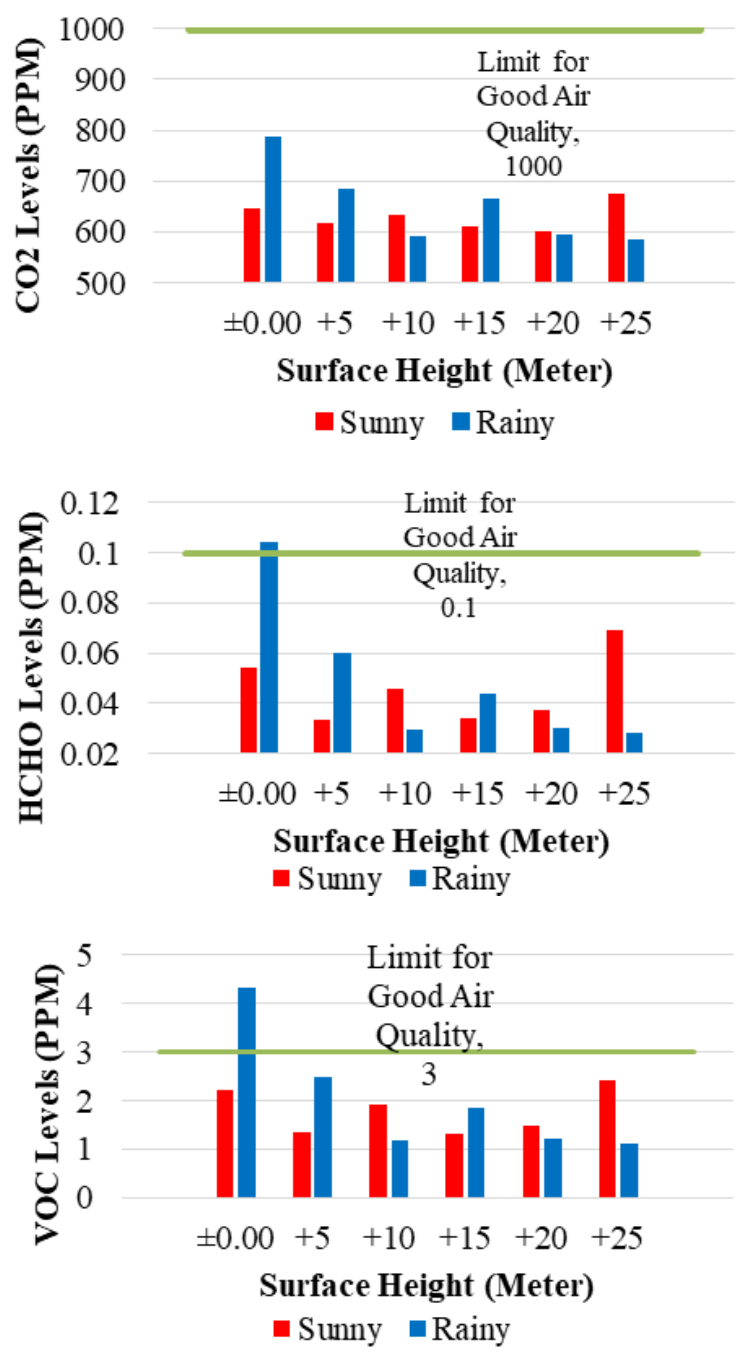

Figure 4. Average pollution levels in the Makassar Bosowa Tower Parking Building

Measurements of air temperature and humidity were carried out on each floor, were carried out on each floor at an altitude of $\pm 0.00,+5.00,+10.00,+15.00,+20.00$, and +25.00 Meters based on building level, and were carried out during sunny and rainy weather with each measurement result can be seen in Fig. 5. 

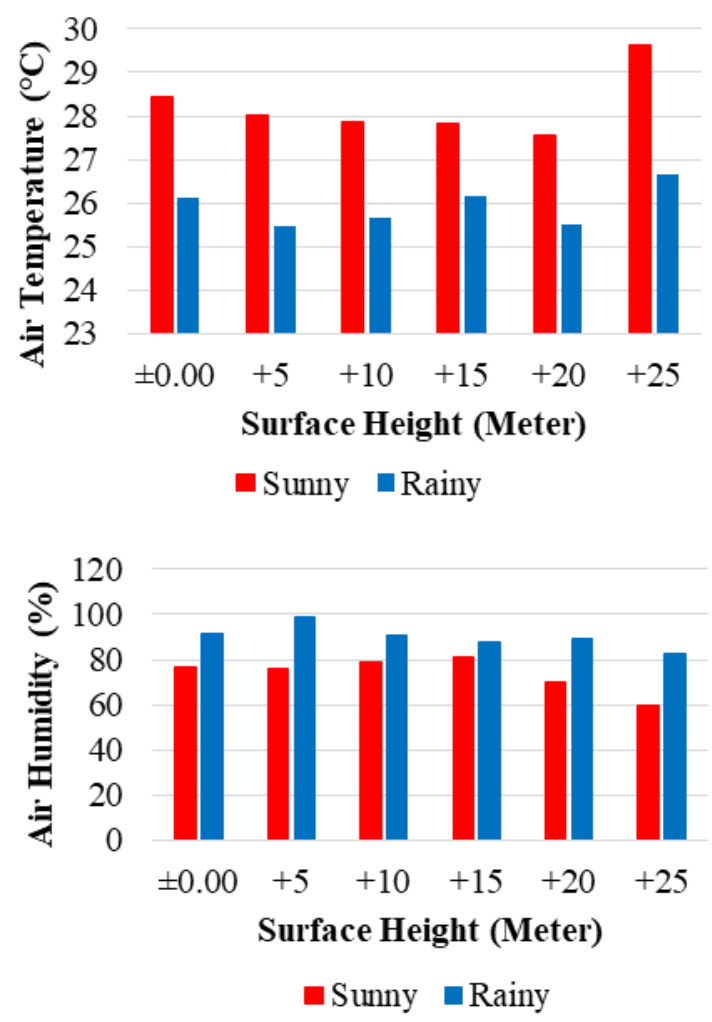

Figure 5. Air temperature and humidity measurement at the Makassar Bosowa Tower Parking Building
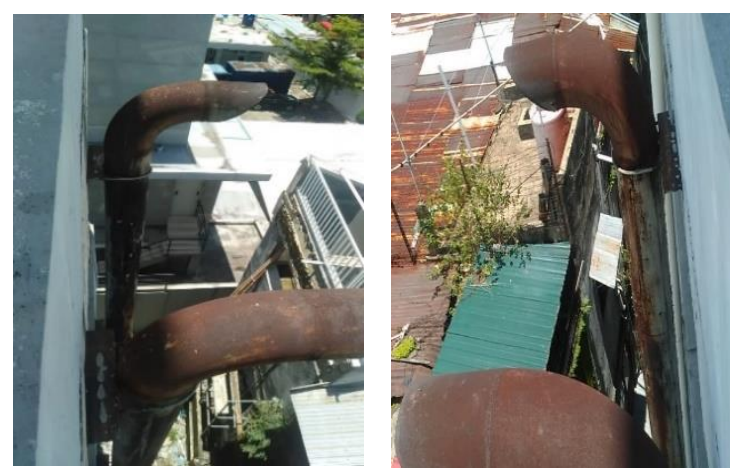

Figure 6. HVAC exhaust pipe in Makassar Bosowa Tower Parking building

The measurement shows that when the weather is sunny, the highest air pollution level is at an altitude of +25.00 meter, because at that altitude is an area close to the HVAC exhaust pipe from the Makassar Bosowa Tower, which operates optimally when the weather is sunny, The average level of air pollution that exceeds the limit for good air quality is only found in Carbon Monoxide (CO), this happens because the parking building is a place for motorized vehicles to pass which is the main source of $\mathrm{CO}$.

Dangerous pollution such as Carbon Monoxide, Carbon Dioxide, Volatile Organic Compound, can be created from daily human activities, some building materials, and household products is a major source of indoor pollution, such as Formaldehyde, Benzene, Ethyl Benzene, Toluene, Xylene, and Styrene [16], these substances are pollutants that released from the exhaust fan, to maintain air quality inside the main building of Makassar Bosowa Tower.

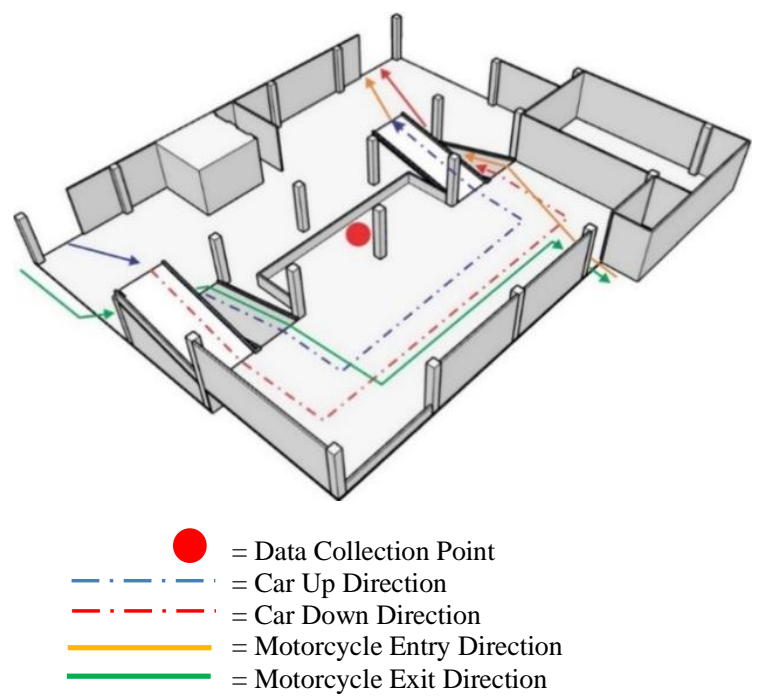

Figure 7. Vehicle flow at an altitude \pm 0.00 at the Makassar Bosowa Tower Parking building

During rainy weather, the highest air pollution level is at an altitude of \pm 0.00 meters $(\mathrm{CO}=78.98$ PPM, $\mathrm{CO}_{2}=788.25$ PPM, $\mathrm{HCHO}=0.1$ PPM, VOC=3.98 PPM), because at that altitude is an area with a high intensity of vehicular traffic, because it is not only traversed by fourwheeled vehicles, but also by two-wheeled vehicles, and during the rainy weather air humidity increases $(>80 \%)$, where air humidity can precipitate air pollution, resulting in average levels of $\mathrm{HCHO}$ and VOC at an altitude of \pm 0.00 , exceeding the limit for good air quality.

\subsection{Effect of weather changes on the air quality}

In this research, data were collected in different weather conditions, which is sunny and rainy, to find out if there was a change in air pollution levels in two different weather conditions, the "Mann Whitney" test was carried out, with the "Mann Whitney" equation and the results obtained are as follows.

$$
U_{1}+U_{2}=R_{1}-\frac{n_{1}\left(n_{1}+1\right)}{2}+R_{2}-\frac{n_{2}\left(n_{2}+1\right)}{2}
$$

Based on the test results, it shows that the significance value of each level of air pollution based on weather changes, all of them show values above 0.05 (sig. > 0.05), where the significance value of Carbon Monoxide (CO) is 0.753 , Carbon Dioxide (CO2) is 0.139 , Formaldehyde (HCHO) is 0.859 , and Volatile Organic Compound (VOC) is 0.890 , so generally the weather changes does not affect the air quality, therefore, a more in-depth study of changes from the air temperature and humidity to the air pollution.

Table 3. Mann Whitney test result of the effect of weather changes on the air pollution

\begin{tabular}{ccccc}
\hline & \multicolumn{3}{c}{ Test Statistics ${ }^{*}$} & \\
\cline { 2 - 5 } & $\mathrm{CO}$ & $\mathrm{CO}_{2}$ & $\mathrm{HCHO}$ & VOC \\
\hline Mann- & 42575 & 40171 & 42853 & 42933 \\
Whitney U & & 83536 & 86218 & 86298 \\
Wilcoxon W & 85940 & -1.479 & -.177 & -.139 \\
Z & -.315 & .139 & .859 & .890 \\
$\begin{array}{c}\text { Asymp. Sig. } \\
\text { (2-tailed) }\end{array}$ & .753 & & &
\end{tabular}


Weather changes will affect the temperature and humidity, because when the sunny weather, the air temperature will increase and the humidity will decrease, and vice versa, to determine the correlation between levels of air pollutants $\left(\mathrm{CO}, \mathrm{CO}_{2}, \mathrm{HCHO}\right.$, and TVOC) with temperature and air humidity, a test was carried out, called "Spearman" correlation test, where the "Spearman" correlation test equation and the results obtained are as follows.

$$
r_{s}=\rho_{r g X, r g Y}=\frac{\operatorname{cov}(\operatorname{rg} X, \operatorname{rg} Y)}{\sigma r g X \sigma r g Y}
$$

The correlation value according to Young [17] is categorized as follows:

- $<0.2$, is either positive or negative, the correlation is negligible or very weak

- $0.2-0.4$, either positive or negative, low or weak correlation

- $0.4-0.7$, both positive and negative, a strong correlation

- 0.7 - 0.99, both positive and negative, high correlation, very strong

- 1 , both positive and negative, perfect correlation

Based on the test results, it shows that air temperature does not affect air pollution levels $\left(\mathrm{CO}, \mathrm{CO}_{2}, \mathrm{HCHO}\right.$, and VOC), air humidity levels almost have no effect on all of the air pollution levels except for $\mathrm{CO}_{2}$ levels, where $\mathrm{CO}_{2}$ levels have a very weak and even negligible correlation, which is 0.132 and has a positive correlation, which means that if the air humidity increases, the $\mathrm{CO}_{2}$ level will also increase.

\subsection{Effect of motorized vehicle and surface height on the air quality}

Details about vehicle capacity, vehicle units that making reservations, and vehicle traffic in each parking area at different surface heights, on the Makassar Bosowa Tower Parking Building can be seen in Table 5.

Table 4. Spearman correlation test results of correlation between air temperature and humidity with air pollution levels

\begin{tabular}{ccccc}
\hline & $\mathrm{CO}$ & $\mathrm{CO}_{2}$ & $\mathrm{HCHO}$ & VOC \\
\hline Air Temperature & 0.049 & -0.007 & 0.045 & 0.045 \\
Air Humidity & 0.016 & $0.132 * *$ & 0.031 & 0.03 \\
\hline
\end{tabular}

**Correlation is significant at the 0.01 level (2-tailed).

Table 5. Number, average occupancy, and intensity of motorized vehicle traffic

\begin{tabular}{ccccc}
\hline $\begin{array}{c}\text { Surface } \\
\text { Height }\end{array}$ & $\begin{array}{c}\text { Vehicle } \\
\text { Capacity } \\
\text { (Unit) }\end{array}$ & $\begin{array}{c}\text { Reservation } \\
\text { (Unit) }\end{array}$ & $\begin{array}{c}\text { Average } \\
\text { Occupancy }\end{array}$ & $\begin{array}{c}\text { Average } \\
\text { Trafic } \\
\text { Intensity }\end{array}$ \\
\hline \pm 0.00 & 15 & 15 & Full & Very High \\
\pm 5.00 & 24 & 8 & Full & High \\
\pm 10.00 & 26 & 10 & Full & High \\
\pm 15.00 & 28 & & 3/4 Filled & High \\
\pm 20.00 & 28 & & $1 / 2$ Filled & Low \\
\pm 25.00 & 28 & & $1 / 4$ Filled & Very low \\
\hline
\end{tabular}

Table 6. Spearman correlation test results of surface altitude to air pollution levels in different weather

\begin{tabular}{lcccc}
\hline & $\mathrm{CO}$ & $\mathrm{CO}_{2}$ & $\mathrm{HCHO}$ & TVOC \\
\hline Sunny & -0.019 & -0.07 & -0.01 & -0.013 \\
Rainy & $-0.253 * *$ & $-0.329 * *$ & $-0.238 * *$ & $-0.24 * *$ \\
\hline **Correlation is significant at the 0.01 level (2-tailed)
\end{tabular}

The table above shows that the higher the surface height at a parking area, the number of vehicles and the intensity of vehicle traffic will decrease, this is following the results of measurements of the Carbon Monoxide (CO), where the higher the surface elevation, the $\mathrm{CO}$ levels will decreases, except on sunny days at an altitude of +25.00 meters, where CO levels are very high, due to the operation of the HVAC exhaust system from the Makassar Bosowa Tower.

Surface altitude will affect air quality because it is influenced by the number and intensity of motorized vehicle traffic, therefore the correlation between surface height and air pollution levels is tested using the "Spearman" correlation test, with results that can be seen in Table 6.

Based on Table 6, it can be seen that when the day is sunny, the surface elevation does not correlate with the level of air pollution, this condition occurs because the HVAC operating system in the building reduces the effect of differences in surface height on air quality. During the rainy day, surface elevation correlates with all levels of air pollution, although the correlation is weak $(0.2-0.4)$, and the correlation is negative, which mean that if the surface elevation increase, the air pollution levels will decrease.

\section{Conclusion}

The air quality in the Makassar Bosowa Tower Parking Building when viewed from the pollutant Carbon Monoxide (CO), as a whole has been exceeded the limit of good air quality for humans (>9 PPM). Overall levels of Carbon Dioxide $\left(\mathrm{CO}_{2}\right)$ are still within the limits for good and safe air quality for human habitation because they are still below 1000 PPM. The levels of Formaldehyde (HCHO) and Volatile Organic Compound (VOC), most showed that the average level was already at a safe level, except at an altitude of \pm 0.00 Meters which had passed the safe level ( $>0.1 \mathrm{PPM}$ for HCHO and $>3$ PPM for VOC). There is no effect from weather changes on the air quality, in terms of changes in air pollution $\left(\mathrm{CO}, \mathrm{CO}_{2}, \mathrm{HCHO}\right.$, and TVOC). The results from the test on changes in air temperature and humidity, to the air pollution levels, only found a very weak positive correlation, between Air Humidity and $\mathrm{CO}_{2}$ levels.

Results from the observations during rainy weather show that the higher the parking area, the number and intensity of vehicle traffic will decrease, according to the analysis results which show that the higher the building surface, the pollution content from the vehicle decreases. When the weather is sunny, the HVAC exhaust pipe operates optimally, so that increasing the level of air pollution, especially at an altitude of +25.00 meters in the Makassar Bosowa Tower Parking Building, even though the vehicle traffic is very low in the parking area. 


\section{References}

[1] N. D. Rahayu, B. Sasmito, and N. Bashit, "Analysis of the Effect of the Indian Ocean Dipole (IOD)Phenomenon on the Java Island Rainfall.," Geod. Undip J., vol. 7, no. 1, 2018. [in Bahasa]

[2] Ronalyw, "Canadian Investors are Interested in Makassar," 2019. [Online]. Available: https://beritakotamakassar.fajar.co.id/berita/2019/08/28/investork anada-lirik-makassar. [Accessed: 11-Jul-2020]. [in Bahasa]

[3] H. Suyanto, "Urban Air Quality Management," Gema Teknol., vol. 16, no. 2, 2011. [in Bahasa]

[4] Ismiyati, D. Marlita, and D. Saidah, "Air Pollution Due to Motor Vehicle Exhaust Emission,” Manaj. Transp. Logistik J., vol. 1, no. 3, 2014. [in Bahasa]

[5] D. B. Istantinova, M. Hadiwidodo, and D. S. Handayani, "Effect of Wind Speed, Humidity and Air Temperature on Concentration of Sulfur Dioxide (SO2) Pollutant Gas in Ambient Air around PT. Inti General Yaja Steel Semarang," Manaj. Transp. Logistik $J .$, vol. 1, no. 3, 2013. [in Bahasa]

[6] H. A. Belgaman, S. Lestari, and H. Lestari, "Urban Heat Island Study and Its Relation to Changes in Climate Temperature Parameters and Rainfall Using Landsat TM Satellite Imagery Case Study of DKI Jakarta and Surrounding Areas.," Sains Teknol. Modif. Cuaca J., vol. 13, no. 1, 2012. [in Bahasa]

[7] A. R. Mohamed, T. L. Keat, and I. Dahlan, Introduction to the Air Pollution. Malaysia: University Sains Malaysia, 2015. [in Melayu]

[8] Indonesia Minister of Health, "Regulation No. 1077 Concerning Guidelines for Indoor Air Sanitation," 2011. [in Bahasa]
[9] R. R. Tangdiongga, L. C. Mandey, and F. Lumoindong, "Chemical Analysis of Formaldehyde in Melamine Tableware by Visible Light Spectrophotometry," Ilmu dan Teknol. Pangan J., vol. 3, no. 1, 2015. [in Bahasa]

[10] Ismail, "Volatile Organic Compound," 2011. [Online]. Available: www.healthsafetyprotection.com. [Accessed: 01-Mar2021]. [in Bahasa]

[11] A. D. R. Marhaeni, "Effect of Meteorological Factors on Fluctuations in PM10 and O3 Concentrations in DKI Jakarta.," Bogor Agricultural University, 2018. [in Bahasa]

[12] K. Prabowo and M. Burhan, Healthy Air. Indonesia, 2018.

[13] M. Kasiram, Research Methodology: Reflection on the Development of Understanding and Mastery of Research Methodology. Malang: UIN Malang Press, 2008. [in Bahasa]

[14] S. Awwaabiin, "Quantitative Research: Definition, Purpose, Types and Steps to Do It.," 2021. [Online]. Available: www.penerbitdeeppublish.com. [Accessed: 17-May-2021]. [in Bahasa]

[15] J. Waeytens and S. Sadr, "Computer-aided Placement of air quality using adjoint framework and sensor features to localize indoor source emission," Build. Environ., vol. 144, 2018.

[16] A. Abdullah, "Monitoring of Air Ducting Using Mechanical Robot for Indoor Air Quality (IAQ) Improvement," Universiti Tun Hussein Onn Malaysia, 2013.

[17] C. Trihendradi, Step by Step SPSS 16 Statistical Data Analysis. Yogyakarta: Andi Offset, 2009. [in Bahasa] 